\title{
AUTUMN MIGRATION OF BIRDS OVER POLONYNA BORZHAVA (UKRAINIAN CARPATHIANS)
}

\author{
O. Dubovyk ${ }^{1}$, A. Bokotey ${ }^{2,3}$, L. Pokrytiuk ${ }^{4}$, V. Bodnar ${ }^{4}$, Yu. Strus ${ }^{3,4,5}$, O. Ruchko ${ }^{4}$ \\ ${ }^{1}$ Ivan Franko National University of Lviv, \\ vul. Hrushevskoho, 4, Lviv, 79005 Ukraine \\ E-mail:oadubovyk@gmail.com \\ ${ }^{2}$ Ukrainian National Forestry University, \\ vul. Generala Chuprynky, 103, Lviv, 79057 Ukraine \\ E-mail: bokotey.a@gmail.com \\ ${ }^{3}$ State Museum of Natural History, NAS of Ukraine, \\ vul. Teatralna, 18, Lviv, 79008 Ukraine \\ ${ }^{4}$ West-Ukrainian Ornithological Society, \\ vul. Teatralna, 18, Lviv, 79008 Ukraine \\ ${ }^{5}$ Nature reserve "Roztochia", \\ Sichovyh Striltsiv, 7, Ivano-Frankove, Lviv Region, 81071 Ukraine
}

Autumn Migration of Birds over Polonyna Borzhava (Ukrainian Carpathians). Dubovyk, O., Bokotey A., Pokrytiuk, L., Bodnar, V., Strus, Yu., Ruchko, O. - Bird migration occurring on the Polonyna Borzhava ridge was studied. Material was collected during 52-days in 307 hours from September till November 2018. It was found that despite difficult terrain and variable weather conditions at least 49 species of birds migrate over Polonyna Borzhava. Among them the following species dominate: Chaffinch, Fringilla coelebs, Common Crane, Grus grus, Eurasian Siskin, Spinus spinus, Common Wood Pigeon, Columba palumbus, Great Tit, Parus major, Goldfinch, Carduelis carduelis, Water Pipit, Anthus spinoletta, Blue Tit, Cyanistes caeruleus, and also raptors: Sparrowhawk, Accipiter nisus, Common Buzzard, Buteo buteo, Goshawk, Accipiter gentilis, Hen Harrier, Circus cyaneus, Marsh Harrier, Circus aeruginosus and other species. Among detected species six are under protection of the Red Data Book of Ukraine: Common Crane, Hen Harrier, Stock Dove, Columba oenas, Alpine Accentor, Prunella collaris, Osprey, Pandion haliaetus, and Peregrine Falcon, Falco peregrinus. Median date of the overall bird passage falls on 9 October. Passage dynamics differs among species. Most of species prefer flight heights not higher than $55 \mathrm{~m}$ above the ridge, but some numerous species choose higher altitudes, for instance Wood Pigeon $(85.6 \pm 62.7 \mathrm{~m})$, and Common Crane $(227.5 \pm 62.5 \mathrm{~m})$.

Key words: autumn bird migration, Carpathians, Borzhava mountain ridge, Transcarpathian Region, Ukraine. 


\section{Introduction}

Today negative processes in the Carpathian region, caused by human activity are actively happening (Várallyay, 2006; Murava \& Korobeinykova, 2016; Mihai et al., 2017), that probably can cause global changes in future (Gilroy et al., 2016; Dyderski et al., 2018). At the same time research dedicated to studies of the influence of those processes on natural ecosystems are in the "embryonic" state (Gurung et al., 2009).

The level of knowledge and understanding of bird fauna in Ukrainian Carpathians remains quite low, despite the occurrence of strong academic centers on adjacent territories and despite the presence of many nature protection sites in the region. The last major work on this subject, the monograph "Birds of the Soviet Carpathians" by F. J. Strautman was published in 1954. While there are some works devoted to breeding birds and to the biology of certain species, in the aspect of bird migrations, Ukrainian Carpathians remain a white spot (Bashta, 1999).

The first detailed works describing the migration of birds in Ukrainian Carpathians are the cycle of publications by F. J. Strautman $(1953,1957)$, in which value of river valleys and mountain ridges for migrating birds was proved on the basis of specific examples.

Among the first researchers who emphasized the need for systematic studies of bird migrations in the Carpathians were I. V. Vainagiy and O. E. Lugovoy (Second All-Soviet-Union Ornithological Conference on bird migrations, 1978). They suggested creating a station for bird ringing and migration studies. O. E. Lugovoy continued to elaborate on the topic and published the work about bird migrations in valleys of rivers Tysa and Uzh (Lugovoy, 1992, 1996). In 1984-1985 ornithologists from Kyiv studied spring migration of birds in Volovets, Mizhgiria, Rahiv and Tiachiv districts of Transcarpathian region (Poluda et al., 1992).

During the last decades, the interest in migration studies in mountains decreased significantly. But with the development of wind-energy industry in Ukraine, and in the Carpathians particularly, the value of existing data about movements of birds over mountain ridges increased much, and new studies began to emerge with high intensity. So far there is only one publication of Bokotey et al. (2013) about studies of birds on the territory of planned wind plant in Turka District of Lviv Region.

It is known, that when passing Borzhava mountain ridge, following the route Podolian Vysotchyna East Beskids - Polonynsky Beskids - Transcarpathian Lowland the highest barrier is the range Polonyna Borzhava (1000-1500 $\mathrm{m}$ a. s. l., the highest point $1681 \mathrm{~m}$ a. s. l., length in direction from SE to NW approximately $50 \mathrm{~km}$ and width $3-4 \mathrm{~km}$, sometimes up to $10 \mathrm{~km}$ ).

Hitherto, the detailed information concerning the migration of birds over this mountain range is absent. During the last few years, this range is intensively studied by specialists from different branches of science because of the possibility of building a wind power plant there.

The aim of this work is to find out peculiarities of autumn bird migration over Polonyna Borzhava, namely: species composition, numbers, main movement directions, passage dynamics and altitude preferences of different species.

\section{Material and methods}

Materials for this paper were the bird counts conducted in the period between the second decade of September and the first decade of November in 2018.

Counts were done on 15 stationary observation sites and on routes between them (fig. 1), distributed between five defined zones of the ridge: (1) mountains Voskresenskyi Verkh (Tsytska) - Temnatyk - Play; (2) footage of mt. Velyky Verkh (middle of the ridge); (3) areas adjacent to mt. Hymba; (4) mountains Zhyd Mahura (Magura-Zhyde) - Hrab - Shyrokii Verkh; (5) vicinities of mt. Stiy. We divided the ridge in this way because of the lack of observers: there should be at least one observer on each peak simultaneously during the whole period of study for more reliable results. Thus, in cases of observations over a saddle between peaks we assumed that this observation belongs to the zone of observer location.

The total duration of observations is equal to 307 hours. In average, during the 52 -days period (between 14 September and 4 November 2018) observations duration was 4 hours and 20 minutes per day ( $\pm 3 \mathrm{hr} 25 \mathrm{~min}$ $\mathrm{SD} ; \pm 28 \mathrm{~min} \mathrm{SE}$ ), ranging from 1 to 11 hours per day. Counts were performed not every day, and during the observation period, 38 days were spent on surveys.

While observing birds we fixed numbers, minimal and maximal height of flyover, and direction of movements. The height of flight was estimated using appropriate landmarks on the area (meteorological tower, high trees, etc.). While conducting the analysis, minimal and maximal heights of flight were averaged. Directions of movements were recorded using 8 compass points: $\mathrm{N}=0^{\circ}, \mathrm{NE}=45^{\circ}, \mathrm{E}=90^{\circ}, \mathrm{SE}=135^{\circ}, \mathrm{S}=180^{\circ}, \mathrm{SW}=225^{\circ}$, $\mathrm{W}=270^{\circ}, \mathrm{NW}=315^{\circ}$.

Data analysis in phenological part of the study was performed for absolute values of bird numbers (individuals per day) and for relative values (individuals per hour, individuals per hour per day). Preliminary data processing was done in Google Spreadsheets and in Microsoft Office Excel 2007, data analysis was implemented in R statistical environment (3.5.1) with the usage of RStudio shell (1.1.447) and additional packages "dplyr", "xtable", "RedaS", and "ggplot2". Maps were prepared in QGIS 2.18.25.

Altitudinal preferences of different species were estimated as a mean value of flights in meters with a value of standard deviation following after. Average angle (azimuth) of flight direction was calculated as a mean of circular quantities using the function of 2-argument arctangent "atan2" (Miller et al., 2010). 


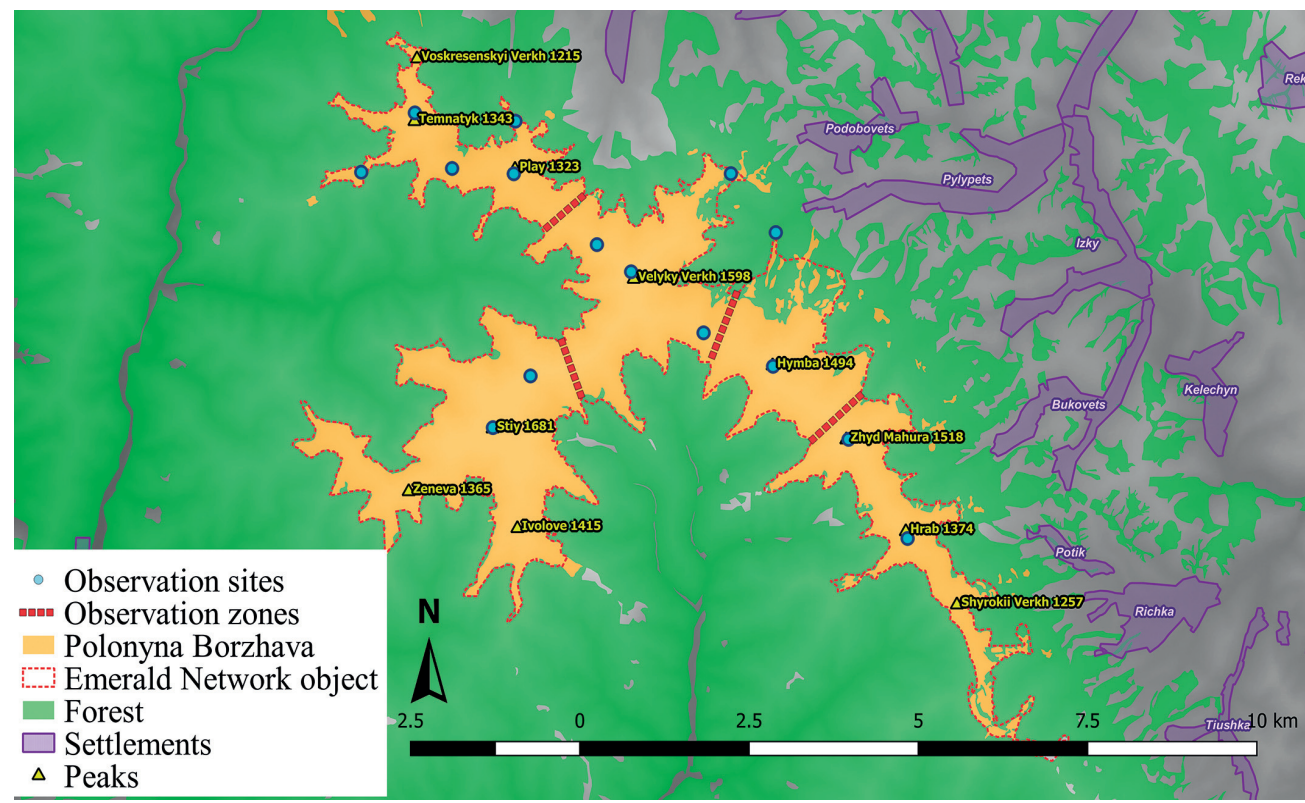

Fig. 1. Observation sites used to monitor migration of birds across Polonyna Borzhava in 2018.

To find out preferences in selecting a specific route over the ridge we calculated relative abundance as absolute numbers of birds divided by the total duration of observations in hours, spent on observation sites of a given ridge zone.

We used the taxonomy according to the Handbook of the Birds of the World and BirdLife International international digital checklist of the birds of the world (Version 2, 2017).

\section{Results and discussion}

During the study period, 47 species of birds were detected; some individuals were identified to a genus level (e. g. Falco, Anser, Anthus, Turdus) or to an order (e. g. Falconiformes, Passeriformes), and such data was not used in further analysis.

According to the obtained results, in average $794.89 \pm 1185.91$ SD of birds per day or $199.1 \pm 252.46$ SD birds per hour per day are passing over Polonyna Borzhava in autumn. Taking into account the high dispersion of obtained values, their averaging is not informative. Median passage date falls on 9 October (fig. 2).

Peculiarities of migration of individual species are as follows (table 1):

Chaffinch, Fringilla coelebs L. The most numerous autumn migrant - in total 27,037 individuals were counted. In average, during one day, up to 771.5 ind. or $116.47 \pm 151.65$ $\mathrm{SD}$ ind. per hour are passing over. The passage is relatively even, the main number of observations occur in the first-third decade of October. There are two peaks in the passage dynamics of the species - on 5-6 and 14-15 October (fig. 3). A big part of migration flow (40\%) goes over saddles near mt. Velykyi Verkh (between mountains of Velykyi Verkh and Play, Velykyi Verkh and Mala Hymba), another part of the flow passes over the whole ridge (fig. 4). Mean height of flight is equal to $35.8 \pm 18.8 \mathrm{~m}$. The south direction is prevailing.

Common Crane, Grus grus (L.). 3,678 birds in 44 flocks were registered. Some observations (flocks consisting of 17 to 150 individuals) fall on the second and third decade of September and on the first decade of October, but noticeable flow (the passage of 28 flocks, in total about 2.5 thousands of birds) was observed on 25 of September (fig. 3). The main passage occurs on sites between mountains Mala Hymba and Magura-Zhyde ( $72 \%$ of flow) and between mt. Temnatyk and mt. Play (23\%) (fig. 4). Common Crane avoids the central part of the ridge ( $5 \%$ ). The average height of flight is equal to $227.5 \pm 62.5 \mathrm{~m}$. The prevailing direction is north-east. 
Table 1. The parameters of migration activity of some bird species in Polonyna Borzhava during autumn 2018

\begin{tabular}{|c|c|c|c|c|c|c|c|c|}
\hline \multirow[t]{2}{*}{ Species } & \multirow{2}{*}{$\begin{array}{l}\text { Total } \\
\text { number } \\
\text { of indi- } \\
\text { viduals }\end{array}$} & \multirow{2}{*}{$\begin{array}{c}\text { Passage } \\
\text { intensity, } \\
\text { ind. per } \\
\text { day }\end{array}$} & \multicolumn{2}{|c|}{$\begin{array}{l}\text { Numbers of } \\
\text { birds, ind. per } \\
\text { hour per day }\end{array}$} & \multirow[t]{2}{*}{$\begin{array}{l}\text { Median } \\
\text { date of } \\
\text { passage }\end{array}$} & \multicolumn{2}{|c|}{ Flight altitude, $\mathrm{m}$} & \multirow{2}{*}{$\begin{array}{c}\text { Average } \\
\text { direction } \\
\text { of flights, } \\
\text { degrees }\end{array}$} \\
\hline & & & mean & $\pm \mathrm{SD}$ & & mean & $\pm \mathrm{SD}$ & \\
\hline Fringilla coelebs & 27037 & 711.5 & 116.5 & 151.7 & 12.10 & 35.8 & 18.8 & 181.0 \\
\hline Grus grus & 3678 & 96.8 & 36.5 & 200.3 & 25.09 & 227.5 & 62.5 & 221 \\
\hline Spinus spinus & 2554 & 67.2 & 10.9 & 16.8 & 14.10 & 32.8 & 20.0 & 180 \\
\hline Columba palumbus & 1872 & 49.3 & 8.0 & 21.3 & 05.10 & 85.6 & 62.7 & 225 \\
\hline Parus major & 1506 & 39.6 & 7.2 & 17.5 & 09.10 & 25.0 & 17.2 & 185 \\
\hline Carduelis carduelis & 841 & 22.1 & 3.6 & 6.3 & 14.10 & 28.8 & 17.1 & 175 \\
\hline Anthus spinoletta & 609 & 16.0 & 2.5 & 6.4 & 19.09 & 23.4 & 8.6 & 159 \\
\hline Cyanistes caeruleus & 572 & 15.1 & 2.2 & 5.4 & 06.10 & 35.5 & 20.8 & 180 \\
\hline Sturnus vulgaris & 363 & 9.6 & 1.6 & 6.3 & 22.10 & 11.1 & 3.1 & 182 \\
\hline Fringilla montifringilla & 285 & 7.5 & 1.2 & 3.3 & 15.10 & 30.9 & 13.1 & 175 \\
\hline Pyrrhula pyrrhula & 171 & 4.5 & 0.7 & 1.9 & 30.10 & 16.4 & 11.6 & 180 \\
\hline Alauda arvensis & 166 & 4.4 & 0.5 & 2.0 & 19.09 & 37.4 & 36.3 & 149 \\
\hline Accipiter nisus & 65 & 1.7 & 0.3 & 0.4 & 15.10 & 40.7 & 31.4 & 182 \\
\hline Motacilla alba & 82 & 2.2 & 0.5 & 1.5 & 21.09 & 33.2 & 28.3 & 166 \\
\hline Buteo buteo & 38 & 1.0 & 0.2 & 0.4 & 08.10 & 261.8 & 60.9 & 183 \\
\hline Accipiter gentilis & 24 & 0.6 & 0.1 & 0.4 & 06.10 & 25.4 & 26.5 & 178 \\
\hline Circus cyaneus & 14 & 0.4 & 0.1 & 0.3 & 22.10 & 61.4 & 46.0 & 180 \\
\hline Falco tinnunculus & 6 & 0.2 & $<0.1$ & 0.1 & 06.10 & 55.0 & 23.5 & 180 \\
\hline
\end{tabular}

Siskin, Spinus spinus L. Intensive passage occurs during whole October and continues with some decrease in the first decade of November (fig. 3). In average 10.9 \pm 16.8 ind. per hour are passing. To overfly the ridge the species usually selects sites located to the south-west from mt. Velykyi Verh (71\% - surroundings of mt. Velykyi Verh, $9 \%$ - surroundings of mt. Play, $19 \%$ - plots near mt. Zhyd Magura) (fig. 4). As a Chaffinch, Siskins overfly the ridge on small heights (32.8 \pm 20.0 meters above ground). Majority of birds fly in south direction.
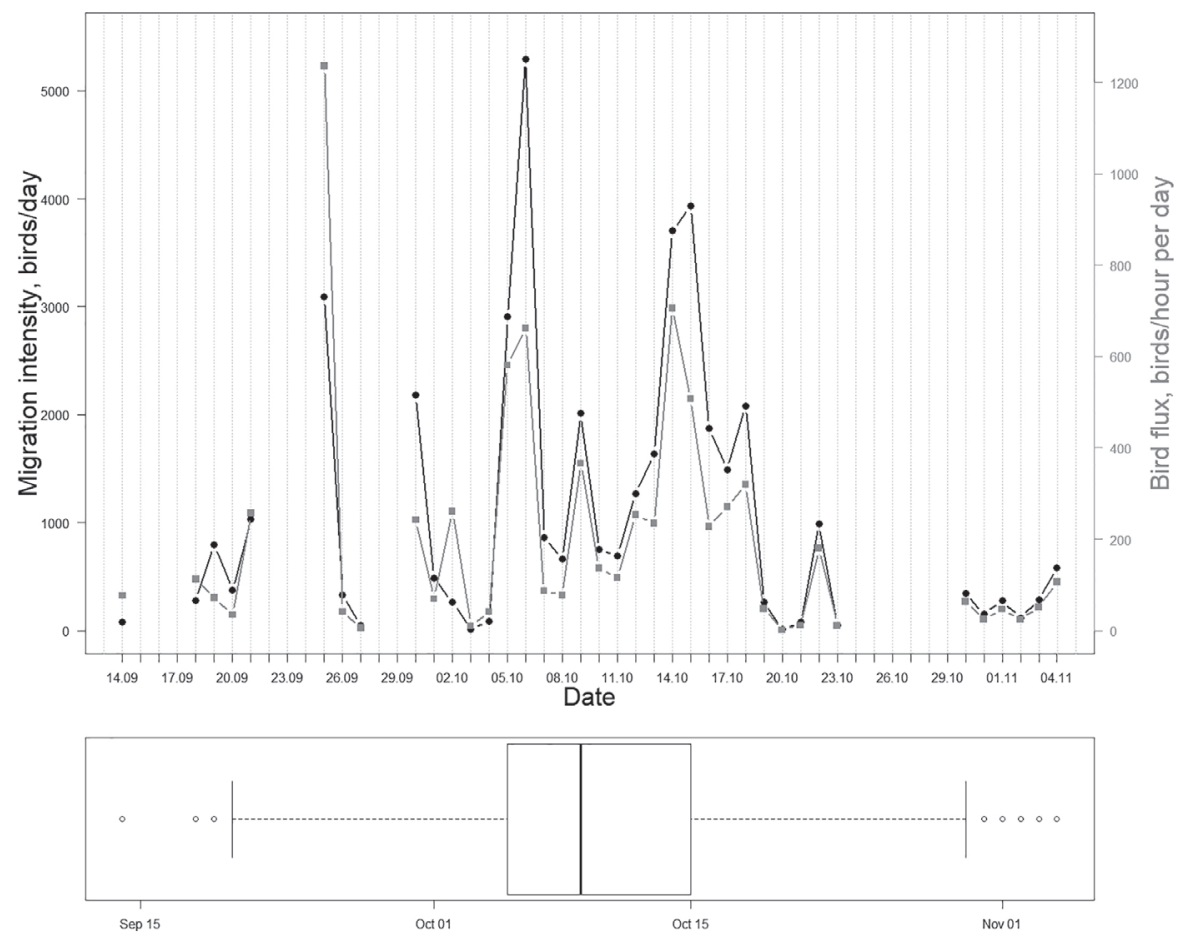

Fig. 2. Overall dynamics of bird autumn passage across Polonyna Borzhava in autumn 2018. 
Wood Pigeon, Columba palumbus L. Abundant species. In contrast to small passerines, big flocks of Wood Pigeons together with Stock Dove, Columba oenas L., are flying just above the forest before and after passing the ridge, so changing the flight high gradually, following the terrain. The mean intensity of a passage in Wood Pigeon is equal to $8.0 \pm 21.3$ ind. per hour and is most prominent in the first decade of October (fig. 3). Wood

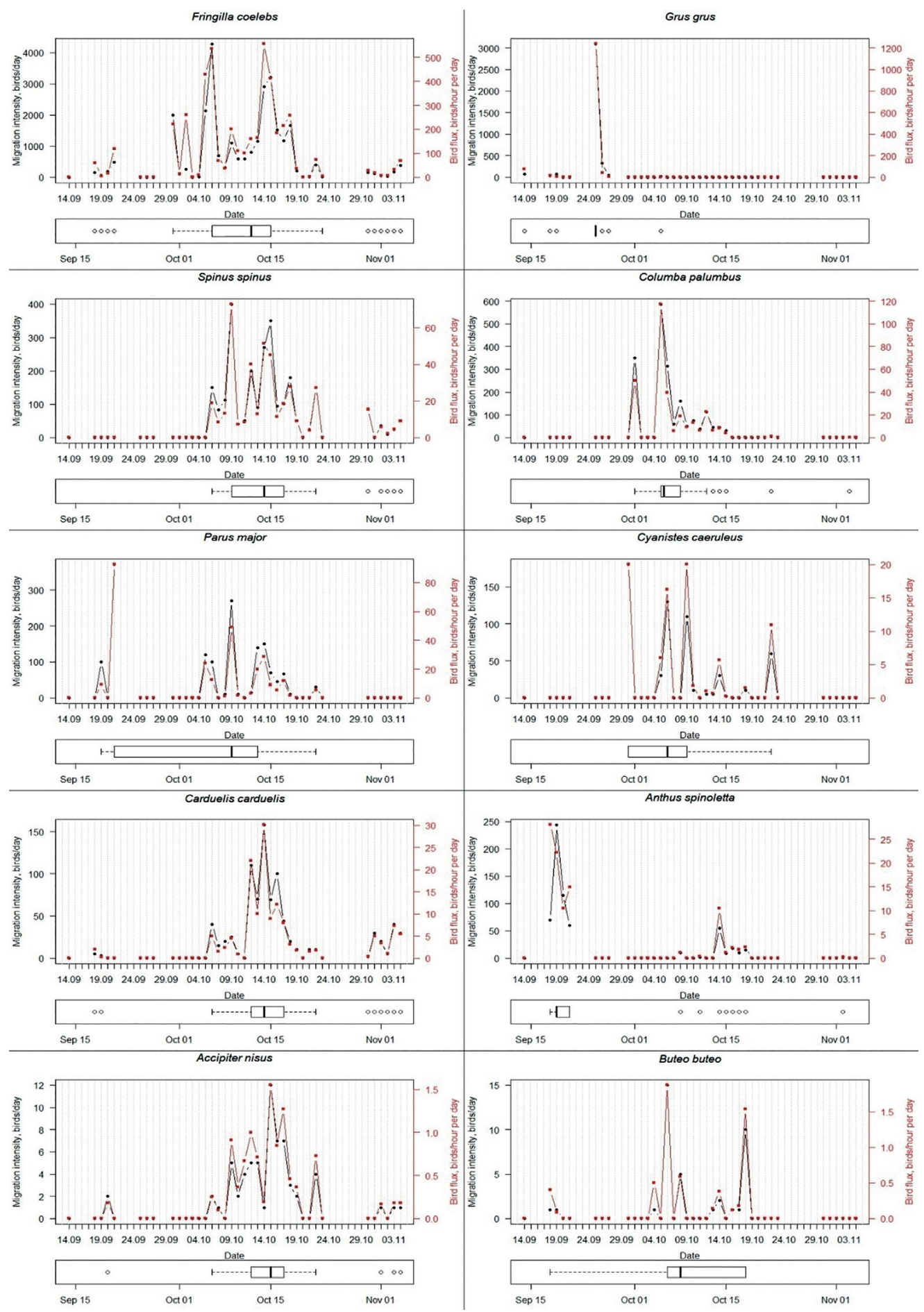

Fig. 3. Dynamics of passage intensity in some common bird species across Polonyna Borzhava in autumn 2018. 
Pigeons and Stock Doves pass over the ridge on the height of $85.6 \pm 62.7$ meters above the ground, selecting vicinities of mt. Velykyi Verkh (50\%), mt. Hymba (29\%), and mt. ZhydMagura (13\%) (fig. 4). Usually, during the passage both species follow the south-west direction. Identification of individual Stock Doves in flocks of Wood Pigeons is sometimes not easy, therefore estimated abundance of the first species is probably underestimated.

Great Tit, Parus major L., and Blue Tit, Cyanistes caeruleus (L.), are abundant migrants. The density of flow equals to $7.2 \pm 17.5$ ind. per hour and $2.2 \pm 5.4$ ind. per hour respectively. Great Tits start to migrate earlier and the peak of migration falls on 21 of September, and the majority of birds pass over the ridge during the second-third decade of September and the first-second decade of October (fig. 3).

Migration peaks of Blue Tits fall on 30 September and 9 October, and intensity of passage is variable during the whole of October (fig. 3). Both species prefer south direction, but

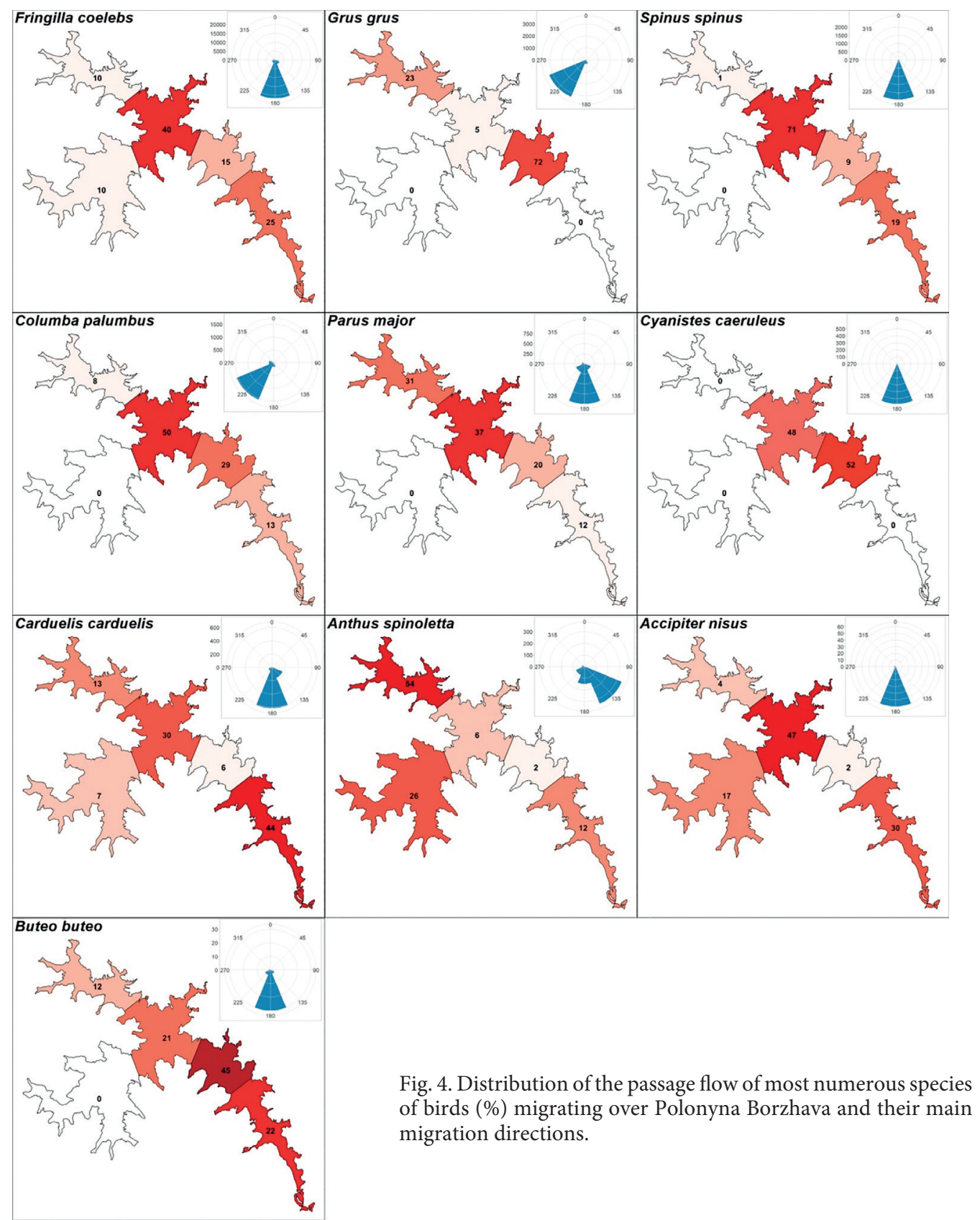


a smaller part of Great Tits was migrating in the south-east and south direction. Great Tits usually use the saddle near mt. Velykyi Verkh (37\%) and mt. Temnatyk (31\%), a smaller fraction migrates over territories near mt. Hymba (20\%) (fig. 4). In average the height of flights equals to $25.0 \pm 17.2$ meters above the ground. Blue Tits usually migrate over plots near mt. Hymba (52\%) and mt. Velyky Verkh (48 \%). On other parts of the ridge, the species was not found. This can be related to sometimes difficult identification of Blue Tits in migrating flocks of Great Tits (fig. 4). We suppose that real numbers of Blue Tits passing over the ridge is bigger than estimated. The mean height of passage in Blue Tit equals to $35.5 \pm 20.8$ meters above the ground.

Goldfinch, Carduelis carduelis (L.), on the Borzhava ridge sporadically occurs during whole autumn migration, but the highest number of observations occurs in the period between the first and the second decade of October (fig. 3). The species selects low places near mountains of Zhyd Magura, Hrab, Shyrokii Verkh (44 \%), vicinities of mt. Velyky Verkh (30\%), Play and Temnatyk (13\%), a small part passes the ridge near mt. Stiy and $\mathrm{mt}$. Zeneva (7 \%), mt. Play (6\%) (fig. 4). Mean height of flights is low and equals to $8.8 \pm 17.1 \mathrm{~m}$ above the ground. The main direction of migration is south.

Water Pipit, Anthus spinoletta (L.), is observed occasionally during the whole autumn. The peak of migration occurs on 18-21 September (fig. 3). It is worth to mention, that as a result of surveys conducted in July 2018 by H. Kuzyo and O. Dubovyk, it was found that Water Pipit is one of the dominating species on the ridge. Therefore differentiation between local breeding birds and migrants is problematic. The birds were treated as migratory if they crossed the ridge in a well-defined direction. Taking into account that migratory birds can stay for some time on slopes, there was probably some overestimation of numbers. The average height of flights is equal to $23.4 \pm 8.6$ meters above the ground. Prevailing direction of movements was south-east, across sites of $\mathrm{mt}$. Temnatyk - mt. Play (54\%) and mt. Stiy (26\%). Smaller numbers of Water Pipits pass over other parts of the ridge (fig. 4).

Alpine Accentor, Prunella collaris (Scopoli). 5 individuals were detected on 16 October on the mt. Riapetska near the mt. Velyky Verkh. Interesting is that those birds, as Water Pipits, were flying in south-east direction on the height about $30 \mathrm{~m}$ above the ground.

Besides the Water Pipit, the Tree Pipit, Anthus trivialis (L.), was detected on the Polonyna Borzhava on 21 September. 47 individuals were flying over the saddle between $\mathrm{mt}$. Velyky Verkh and mt. Hymba in the south-west direction and on the height of $10 \mathrm{~m}$. On 13 October we observed Meadow Pipits, Anthus pratensis (L.) - 18 individuals on the north slope of $\mathrm{mt}$. Play flying over in south direction on the height 5-20 m.

Sparrowhawk, Accipiter nisus L., and Common, Buzzard Buteo buteo L. - are the most abundant species among raptors. The mean intensity of a passage in Sparrowhawk equals to $0.3 \pm 0.4$ ind. per hour. To overpass the ridge this species selects sites near $\mathrm{mt}$. Veleky Verkh (47 \%) and mt. Zhyd Magura - mt. Hrab (30\%), but it was also detected on the whole territory of the ridge (fig. 4). The height of a passage is variable and on average equals to $40.7 \pm 31.4$ meters above the ground (fig. 3 ). The average intensity of a passage of Common Buzzard equals to $0.2 \pm 0.4$ ind. per hour. The species migrates mostly near the mt. Play (45 \%) (fig. 4), with an average height of flights equal to $261.8 \pm 60.9$ meters above the ground (fig. 3). Usually, both species migrate in south direction.

Except for Sparrowhawk and Common Buzzard there are several other species of raptors migrating over Polonyna Borzhava: Goshawk, Accipiter gentilis (L.), Hen Harrier, Circus cyaneus (L.), Marsh Harrier, Circus aeruginosus (L.), Common Kestrel, Falco tinnunculus L., Honey Buzzard, Pernis apivorus (L.), Hobby, Falco subbuteo L., Merlin, Falco columbarius L., Red-footed Falcon, Falco vespertinus L., Peregrine Falcon, Falco peregrinus Tunstall and Osprey, Pandion haliaetus (L.).

Clusterization of average heights of flights which have dispersion higher than " 0 ", in other words for those with a sufficient number of observations, by applying k-mean method (with $\mathrm{k}=3$ ), allows identifying three groups of birds migrating over Polonyna Borzhava. 
Mean heights of flight for those groups are $25.05 \mathrm{~m}, 89.16 \mathrm{~m}$, and $224.23 \mathrm{~m}$ above the ground (fig. 5). The first group consists mostly of passerine birds: Chaffinch, Siskin, Goldfinch, Water Pipit, Greenfinch, Chloris chloris (L.), Brambling, Fringilla montifringilla L., Hawfinch, Coccothraustes coccothraustes L., Bullfinch, Pyrrhula pyrrhula (L.), Linnet, Linaria cannabina (L.), Skylark, Alauda arvensis L., Great Tit, Blue Tit and Coal Tit, Periparus ater (L.), Black Redstart, Phoenicurus ochruros (Gmelin), Dunnock, Prunella modularis (L.), Blackbird, Turdus merula L., Mistle Thrush, Turdus viscivorus L., and Fieldfare, Turdus pilaris L., Spotted Nutcracker, Nucifraga caryocatactes (L.); also, to the group of birds that overpass the ridge on low heights belong Stock Dove, Starling, Sturnus vulgaris L., and some raptors: Sparrowhawk, Goshawk, Common Kestrel, Hobby, Osprey. The second group of species prefers flight heights in the range between 55 and 160 meters. Main species in this group are Marsh Harrier, Hen Harrier, Red-footed Falcon, and also Wood Pigeon, Raven, Corvus corax L., and Barn Swallow, Hirundo rustica L. Among birds that overpass the ridge on high altitudes are Honey Buzzard, Common Crane, and Common Buzzard.

Distribution of migration phenology of birds migrating over Polonyna Borzhava in autumn was studied based on median dates of passage (fig. 6). Migration activity of birds was observed on the studied territory since August. For example, on 27 August 2018 V. Yagodzynskyi observed a Dotterel, Eudromias morinellus (L.) (pers. comm.); also the observation of this species is known on the same locality on 29 August 2009 (Kish, 2017). In the second decade of September medians of a passage of Water Pipit, House Martin, Delichon urbicum (L.), and Skylark are observed. In the third decade of September main migrants are Common Crane, White Wagtail, Motacilla alba L., and Tree Pipit. Median date of passage in the majority of species occurs in October:

- in the first decade - Stock Dove, Marsh Harrier, Chiffchaff, Barn Swallow, Wood Pigeon, Peregrine Falcon, Common Kestrel, Osprey, Fieldfare, Redwing, Turdus iliacus L., Blue Tit, Common Buzzard, Hobby, Woodlark, Great Tit, Black Redstart;

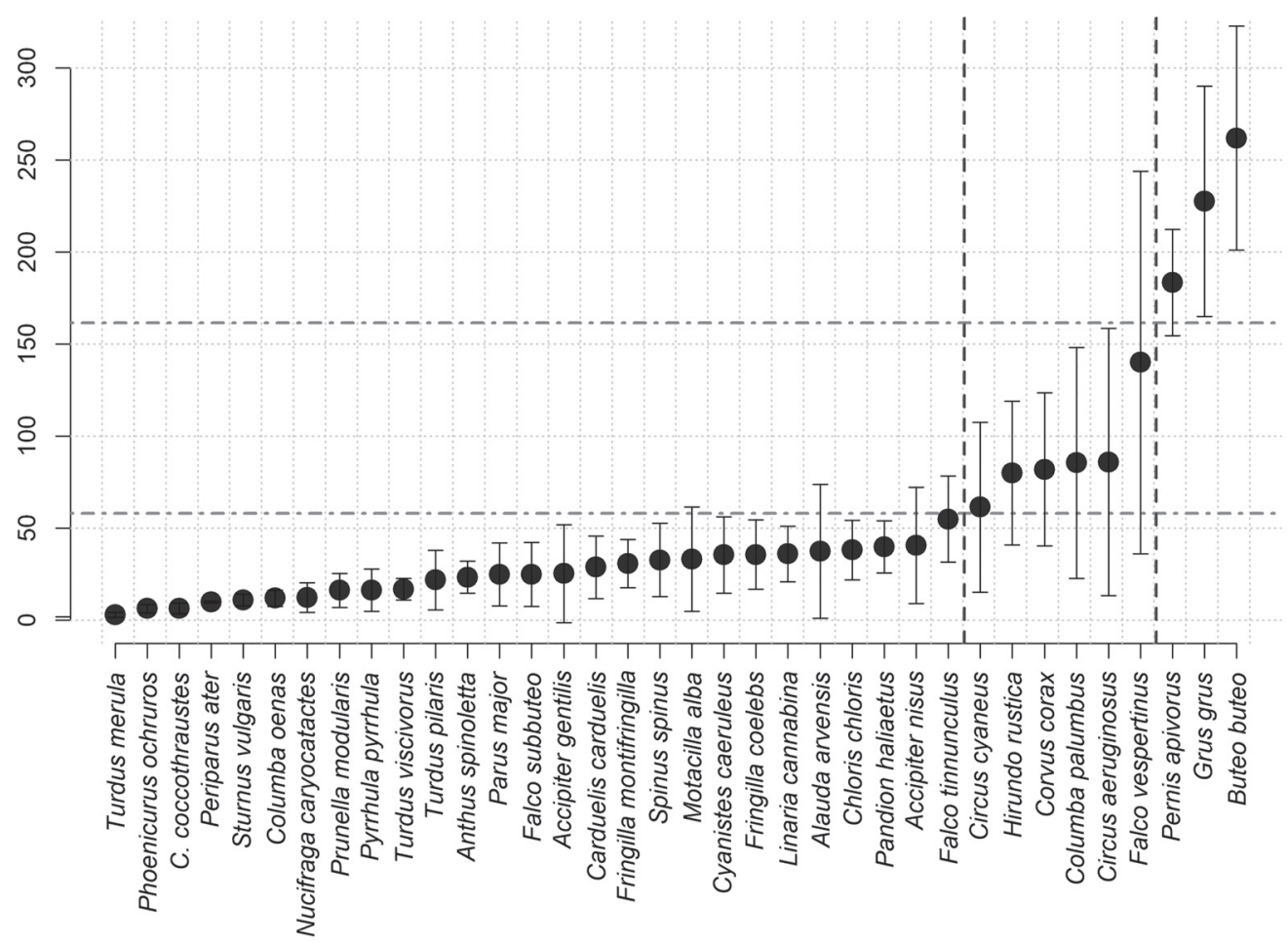

Рис. 5. Passage height preferences $(\mathrm{M}, \pm \mathrm{SD})$ of birds migrating over Polonyna Borzhava mountain ridge in autumn 2018. 


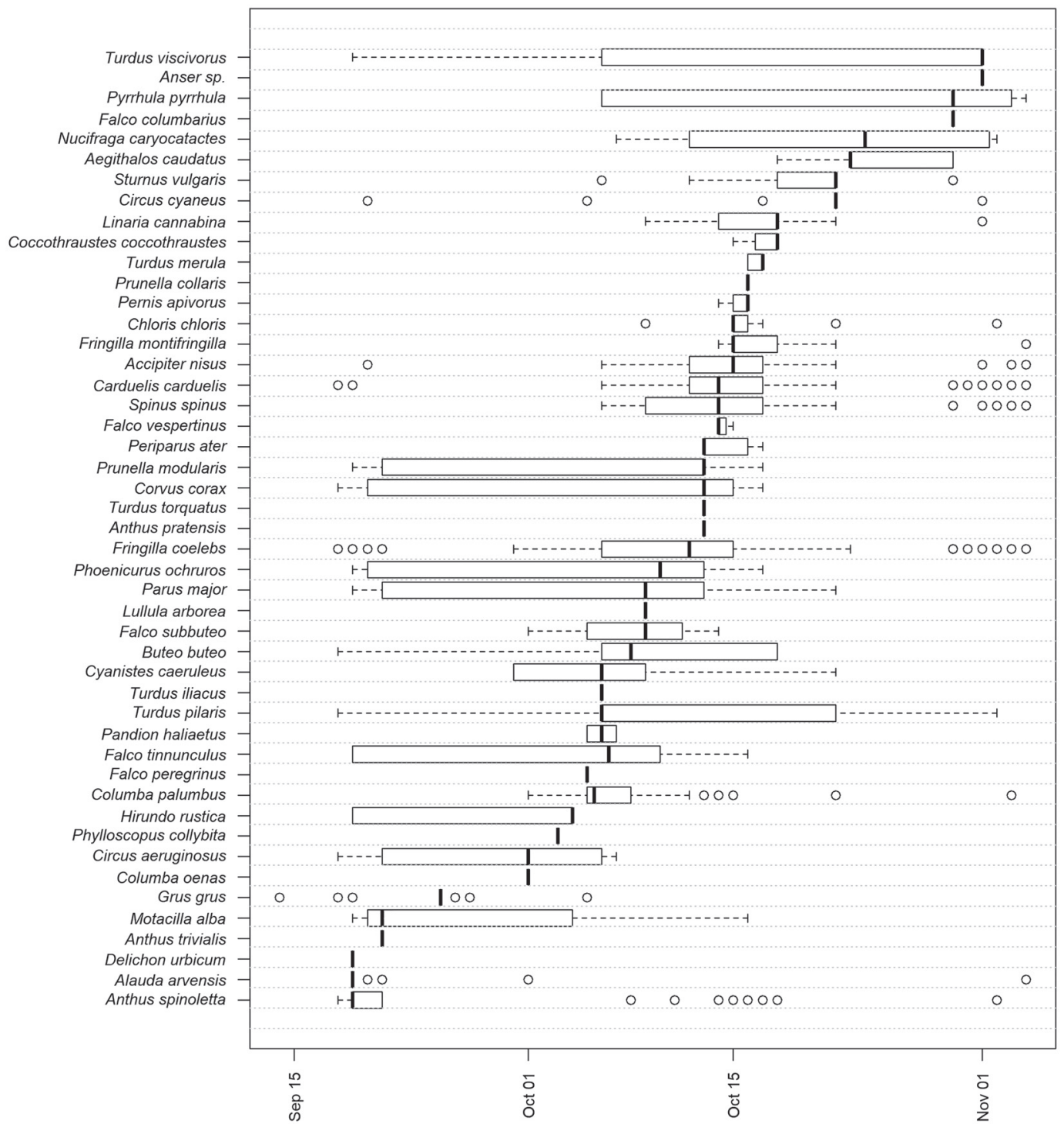

Fig. 6. Passage phenology of birds migrating over Polonyna Borzhava in Autumn 2018.

- in the second decade - Chaffinch, Meadow Pipit, Ring Ouzel, Raven, Dunnock, Coal Tit, Red-Footed Falcon, Siskin, Goldfinch, Sparrowhawk, Brambling, Greenfinch, Honey Buzzard, Alpine Accentor, Blackbird, Hawfinch, Linnet;

- in the third decade - Hen Harrier, Starling, Long-Tailed Bushtit, Aegithalos caudatus (L.), Nutcracker, Merlin, Bullfinch.

The latest migrant with a median date of passage in the first decade of November is Mistle Thrush, which, by the way, was present on the territory during the whole study period.

\section{Conclusions}

Mountain ridge Polonyna Borzhava is an important region in Ukrainian Carpathians for autumn migration of birds, including rare species, which are protected by the Ukrainian Red Data Book: Common Crane, Hen Harrier, Stock Dove, Alpine Accentor, Osprey, Peregrine Falcon. 
At least 48 species of birds migrate over Polonyna Borzhava in autumn. Despite unsuitable conditions for a passage - strong winds, frequent fogs, excessive precipitation, steep hills, big differences in altitudes - there is a strong migration route of passerine birds over the Borzhava ridge, mostly finches, but also the area is important for migrating pigeons, raptors, and for massive passage of Common Crane. However, on the current stage, it is impossible to fully define the role of this particular ridge for bird migrations, because a comparison of species composition and bird numbers between birds that pass over the ridge with those that avoid high altitudes and choose river valleys is needed.

Also, for the relatively complete understanding of migration scale over the Polonyna Borzhava similar studies with the same survey effort in other parts of the Carpathians are needed, especially on territories located to NW and SE relative to Polonynski Beskids. Especially valuable results can be obtained by tagging birds from western regions of Ukraine, Polissia and Baltic states by GPS radio-transmitters.

The authors are grateful to K. Borysenko, Yu. Burlachenko, A. Kogut, and V. Yagodzynskyi for provided data and photos of birds migrating across Polonyna Borzhava. To R. Stefanyshyn and H. Kuzyo for assistance with fieldwork and also to inhabitants of Pylypets village of Mizhgiria District in Transcarpathian Region for help in conducting the research.

\section{References}

Bashta, A.-T. 1999. Breeding bird community of monocultural spruce plantation in the Skolivski Beskids (The Ukrainian Carpathians). Berkut, 8 (1), 9-14.

Bokotey, A., Dzyubenko, N., Strus, I. 2013. Preliminary results of avifauna research in the area of Verkhniodnistrovsky Beskids selected for Smerechanska windfarm building. In: Rusev, I., Stoilovskiy, V., Korzyukov, A., Kivganov, D., eds. The birds and the environment. Odessa, April, 30-35 [In Ukrainian].

Dyderski, M., Paź, S., Frelich, L. E., Jagodziński, A. M. 2018. How much does climate change threaten European forest tree species distributions? Global Change Biology, 24 (3), 1150-1163.

Gilroy, J. J., Gill, J. A., Butchart, S. H. M., Jones, V. R., Franco, A. M. A. 2016. Migratory diversity predicts population declines in birds. Ecology Letters, 19, 308-317.

Gurung, A. B., Bokwa, A., Chełmicki, W., Elbakidze, M., Hirschmugl, M., Hostert, P., Ibisch, P., Kozak, J., Kuemmerle, T., Matei, E., Ostapowicz, K., Pociask-Karteczka, J., Schmidt, L., van der Linden, S., Zebisch, M. 2009. Global change research in the Carpathian mountain region. Mountain Research and Development, 29 (3), 282-289.

Kish, R. 2017. Observation of a Dotterel Eudromias morinellus on the Polonyna Borzhava. Troglodytes. Proceedings of the West-Ukrainian Ornithological Society, 8, 102 [In Ukrainian].

Lugovoy, A. 1992. Visible bird migration in the Upper Tisa river. In: Voynstvenskyi, M., ed. Seasonal bird migrations on the territory of Ukraine. Naukova Dumka, Kiev, 141-152 [In Russian].

Lugovoy, A., Potish, L. 1996. Migration of geese of the genus Anser in the area of the East Carpathians. Berkut, 5 (1), 71-78 [In Russian].

Mihai, B., Săvulescu, I., Rujoiu-Mare, M., Nistor, C. 2017. Recent forest cover changes (2002-2015) in the Southern Carpathians: a case study of the lezer Mountains, Romania. Science of the Total Environment, 599-600, 2166-2174.

Miller, F. P., Vandome, A. F., McBrewster, J. 2010. Mean of circular quantities. Alphascript Publishing, Beau Bassin, 1-88.

Murava, I., Korobeinykova, Y. 2016. The analysis of the waste problem in tourist destinations on the example of Carpathian region in Ukraine. Journal of Ecological Engineering, 17 (2), 43-51.

Poluda, A., Prokopenko, S., Diadycheva, E., Revutskyi, G. 1992. Some features of birds' spring migration in Carpathians. In: Voynstvenskyi, M., ed. Seasonal bird migrations on the territory of Ukraine. Naukova Dumka, Kiev, 133-141 [In Russian].

Strautman, F. 1953. Role of river valleys in distribution of plain bird species to Soviet Carpathians. Dopovidi ta povidomlennya Lvivskoho derzhavnoho universitetu imeni Iv. Franka, 4 (2), 51-54 [In Russian].

Strautman, F. 1957. River valleys in Soviet Carpathians as bird migrations and wanderings routes. In: Kumary, E., ed. Proceedings of Second Baltic ornithological conference. Izdatelstvo Akademii Nauk SSSR, Moscow, 85-89 [In Russian].

Várallyay, G. 2006. Soil degradation and extreme soil moisture regime as environmental problems in the Carpathian basin. Agrokémiaés Talajtan, 55 (1), 9-18 [In Hungarian]. 